\title{
Chemoenzymatic Synthesis of the New 3-((2,3-Diacetoxypropanoyl)oxy)propane-1,2-diyl Diacetate Using Immobilized Lipase B from Candida antarctica and Pyridinium Chlorochromate as an Oxidizing Agent
}

\author{
Esteban Plata ${ }^{1}$, Mónica Ruiz ${ }^{1}$, Jennifer Ruiz ${ }^{1}$, Claudia Ortiz $^{2}$, John J. Castillo ${ }^{1, *(D)}$ \\ and Roberto Fernández-Lafuente ${ }^{3, * \mathbb{D}}$ \\ 1 Escuela de Química, Grupo de investigación en Bioquímica y Microbiología (GIBIM), \\ Edificio Camilo Torres 210, Universidad Industrial de Santander, CEP, 680001 Bucaramanga, Colombia; \\ stbnplata29@gmail.com (E.P.); icmonicaruiz@gmail.com (M.R.); jennifer.ruiz@correo.uis.edu.co (J.R.) \\ 2 Escuela de Microbiología, Universidad Industrial de Santander, 680001 Bucaramanga, Colombia; \\ ortizc@uis.edu.co \\ 3 ICP-CSIC, Campus UAM-CSIC, Cantoblanco, 28049 Madrid, Spain \\ * Correspondence: jcasleon@uis.edu.co (J.J.C.); rfl@icp.csic.es (R.F.-L.); Tel.:+57-320-902-6464 (J.J.C.); \\ +34915854804 (R.F.-L.)
}

Received: 3 August 2020; Accepted: 4 September 2020; Published: 5 September 2020

\begin{abstract}
To exploit the hydrolytic activity and high selectivity of immobilized lipase B from Candida antarctica on octyl agarose (CALB-OC) in the hydrolysis of triacetin and also to produce new value-added compounds from glycerol, this work describes a chemoenzymatic methodology for the synthesis of the new dimeric glycerol ester 3-((2,3-diacetoxypropanoyl)oxy)propane-1,2-diyl diacetate. According to this approach, triacetin was regioselectively hydrolyzed to 1,2-diacetin with CALB-OC. The diglyceride product was subsequently oxidized with pyridinium chlorochromate (PCC) and a dimeric ester was isolated as the only product. It was found that the medium acidity during the PCC treatment and a high 1,2-diacetin concentration favored the formation of the ester. The synthesized compounds were characterized using IR, MS, HR-MS, and NMR techniques. The obtained dimeric ester was evaluated at 100 ppm against seven bacterial strains and two Candida species to identify its antimicrobial activity. The compound has no inhibitory activity against the bacterial strains used but decreased C. albicans and C. parapsilosis growth by $49 \%$ and $68 \%$, respectively. Hemolytic activity was evaluated, and the results obtained support the use of the dimeric ester to control C. albicans and C. parapsilosis growth in non-intravenous applications because the compound shows hemolytic activity.
\end{abstract}

Keywords: chemoenzymatic synthesis; glycerol derivatives; interfacially activated lipase; regioselective hydrolysis; diacetin oxidation; pyridinium chlorochromate; antibacterial activity; antifungal activity; hemolytic activity

\section{Introduction}

Glycerol (propane-1,2,3-triol) is the most abundant by-product generated during transesterification reactions of vegetable oils and animal fats with methanol to produce biodiesel [1-3]. Due to the global population growth and the demand for new energy sources with a low impact regarding $\mathrm{CO}_{2}$ emissions [4,5], the biodiesel industry is developing rapidly, resulting in a high excess of glycerol. Therefore, new processes to convert this alcohol into added-value chemicals have been increasingly explored [6-9]. 
A well-known process for the transformation of glycerol is its esterification or transesterification to monoglycerides, diglycerides, and triglycerides [10,11], molecules that exhibit high nutritional value [12], and are extensively used as emulsifiers in the food, cosmetic, and pharmaceutical industries [13]. At an industrial scale, glycerides are generally prepared using inorganic acid or basic catalysts at high temperatures [14] or by enzyme-catalyzed [15] reactions, such as alcoholysis, glycerolysis, and hydrolysis [16], which, unlike chemical methods, can afford glycerides with high yields and selectivity under mild conditions in the absence of by-products $[17,18]$.

Enzymes are very useful catalysts for organic chemistry because they can be used in a wide range of reactions, and also because they show high reaction rates and selectivity [19]. Amongst the enzymes, lipases have been found to be particularly useful [20,21]. In nature, lipases have the physiological function of hydrolyzing fats and oils. However, in vitro, they can be used in other processes such as amidation [22,23] and esterification [24] reactions. Their high enantiospecificity also makes them suitable for enantiomeric resolution processes $[25,26]$. Due to their regioselectivity and the fact that they can be used under mild conditions in aqueous and organic media $[27,28]$, lipases are preferred as biocatalysts to modify glycerol and its derivates selectively.

Glycerides are molecules that have low water solubility; therefore, they form insoluble drops where lipases act. This action of lipases at the interfaces is the peculiarity of these enzymes. This capacity of lipases is possible due to their mechanism of action, called interfacial activation, which permits lipases to become adsorbed on the hydrophobic surface of the glyceride drops by involving their active center area and, that way, they can act at the interface of these oil drops. In homogeneous media, the active center of lipases is generally isolated from the reaction medium because it is covered with a polypeptide chain called lid (in this "closed" form, the lipase is usually inactive). This lid can move, and when it is shifted, it forms a huge hydrophobic pocket, exposing the active center to the medium, resulting in the "open" and active form of the lipase, with the hydrophilic phase of the lid interacting with areas of the protein surface near the active center [29-31]. This large hydrophobic pocket is very unstable in homogeneous aqueous media. Both conformational lipase forms are in equilibrium, but in the presence of oil drops, the open form becomes adsorbed on the hydrophobic surface of the drops, shifting the conformational equilibrium towards the open form of the lipase and permitting the attack of the glycerides by the enzyme [29,32,33]. This phenomenon has been exploited to immobilize lipases on hydrophobic supports, such as octyl-agarose, which has octyl groups on its surface and can selectively immobilize lipases via interfacial activation. Lipase immobilization is essential in all industrial applications because it allows the separation and reuse of the biocatalyst; studies have shown that immobilization on supports via interfacial activation lends stability, improves selectivity, and enhances catalytic activity [32,34-37].

Oxidation is another way to prepare added-value compounds from glycerol, fine chemicals such as dihydroxyacetone, glyceric acid, and glyceraldehyde, which have found applications in the cosmetics and pharmaceutical industries [38-41]. Considering the three functional groups present in the glycerol molecule (two primary and one secondary hydroxyl groups), selective oxidation of these functionalities is the main aspect to consider when selecting methodologies to prepare the aforementioned molecules, which are usually prepared using expensive metals such as palladium, gold, and platinum as catalysts [42-44]. Chromium (VI)-based oxidants, such as the Collins reagent [45], pyridinium chlorochromate [46], or pyridinium dichromate [47], have been extensively used as oxidizing agents in organic synthesis, due to their efficiency and most importantly because oxidation of alcohols using such types of reagents allows the user to stop the reaction at the aldehyde or carboxylic acid stage if the reaction is properly controlled $[48,49]$.

Glycerol can undergo oligomerization by etherification reactions: two glycerol molecules can condensate to yield diglycerols, which may be linear, branched, or cyclic [50,51]. Low molecular weight glycerol oligomers (PGs) and polyglycerol esters (PGEs) have found applications in the cosmetic, pharmaceutical, and food industries as new products for surfactants, lubricants, cosmetics, and food additives [52-56]. PGs and PGEs are normally obtained from the high temperature etherification 
of glycerol and the esterification with fatty acids in the presence of homogenous or heterogenous catalyst [57-60].

To exploit the regioselectivity of the immobilized lipases and the efficiency of the chromium (VI) oxidants, in this work we propose a new chemoenzymatic methodology in which we used Candida antarctica lipase B immobilized on octyl-agarose support (CALB) to hydrolyze triacetin to 1,2-diacetin, which was subsequently transformed, using PCC, to obtain the new dimeric glycerol ester 3-((2,3-diacetoxypropanoyl)oxy)propane-1,2-diyl diacetate, a molecule which to date has no reported synthesis. To the best of our knowledge, this is the first time that a diglyceride prepared via catalytic hydrolysis with immobilized lipases has been used as the starting material for new and more complex molecules.

\section{Results and Discussion}

\subsection{Immobilization of CALB on Octyl-agarose}

Figure 1 shows the immobilization course of CALB on octyl-agarose, which is a quite rapid immobilization process. As we used an excess of the enzyme, immobilization only accounts for around $50 \%$ of the offered enzyme, with an expressed activity of around 50\% [61].

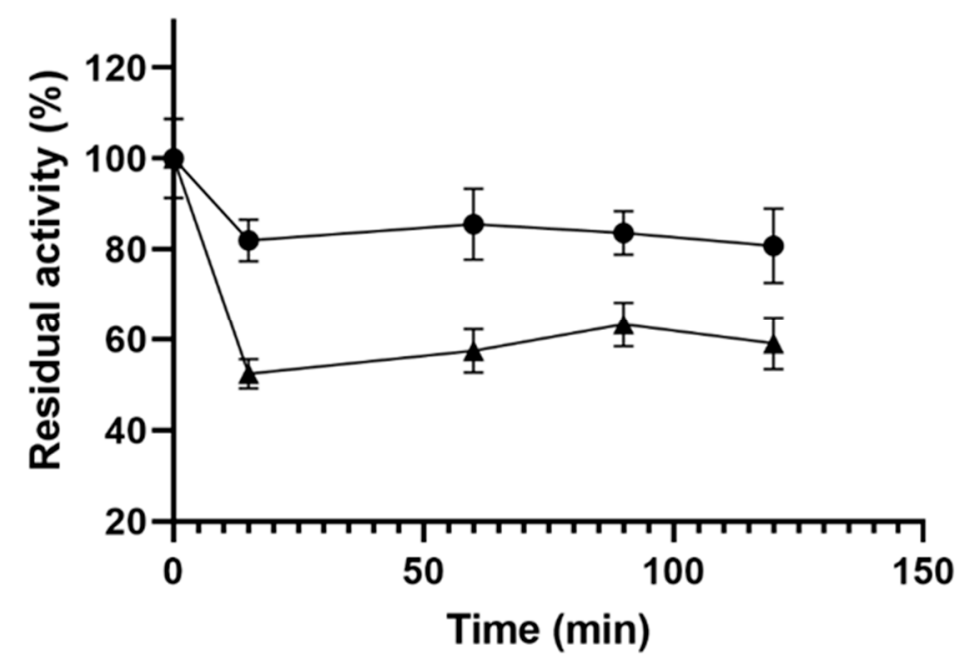

Figure 1. Immobilization course of Candida antarctica lipase B (CALB) on octyl agarose. $(\bullet)$ suspension and $(\boldsymbol{\Delta})$ supernatant.

Compared to other lipases [62,63], in our case there was no hyperactivation of the enzyme upon immobilization, probably since CALB has no large helical lid fully covering the active site and does not exhibit a strong interfacial activation $[33,64,65]$; therefore, its activity in solution is very similar to the activity of the enzyme immobilized on octyl-agarose [66-68], and even decreased due to substrate diffusional problems by the high enzyme loading.

\subsection{Hydrolysis of Triacetin (1) Catalyzed by CALB-OC}

Figure 2 shows the enzymatic hydrolysis of triacetin catalyzed by CALB-OC. In this study, we use CALB-OC, since it has been shown that, like most lipases, CALB-OC is a sn-1,3 regioselective biocatalyst in the hydrolysis of triacetin, so that the hydrolysis of the triglycerides with lipases will produce 1,2-diglycerides and 2-monoglycerides [69-71]. It is interesting to note that, based on previous studies, hydrolysis of triacetin by Novozym 435 (a commercial immobilized preparation of CAL B) exhibited a low yield of diacetin [72], presumably due to high isomerization and production of monoacetins [73,74]. 
<smiles>CC(=O)OCC(COC(C)=O)OC(C)=O</smiles>

(1)

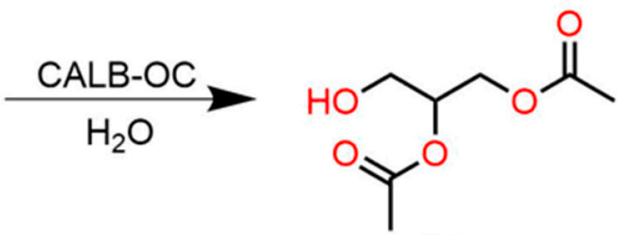

(2)

Figure 2. Regioselective hydrolysis of triacetin (1) to 1,2-diacetin (2) catalyzed by CALB-OC.

To assess the effect of acetonitrile on the hydrolysis of triacetin by CALB-OC and to improve the solubility of triacetin, we evaluated the addition of $20 \%$ acetonitrile to the reaction mixture. Table 1 shows the yield of 1,2-diacetin (2) in the absence and the presence of $20 \%$ acetonitrile (entry 1 ). After 90 min of reaction, 1,2-diacetin (2) and 2-monoacetin were the only detected products and $46.5 \%$ of the triacetin remained non-hydrolyzed. On the other hand, the hydrolysis without acetonitrile (entry 2) increased the yield of 1,2-diacetin (2) to 71\% with an increase in the accumulation of 2-monoacetin. 1,3-diacetin was not detected in any of the two cases [75]. The reduction in the production of 1,2-diacetin (2) in the presence of acetonitrile can be attributed to the fact that organic solvents alter the conformation of the immobilized lipases [76] and could also act as competitive lipase inhibitors [69].

Table 1. Effect of solvents on the triacetin hydrolysis with CALB-OC.

\begin{tabular}{ccccc}
\hline Entry & Solvent & Triacetin (\%) & 1,2-Diacetin (\%) & 2-Monoacetin (\%) \\
\hline 1 & $\begin{array}{c}\text { 20\% acetonitrile/sodium } \\
\text { phosphate } 500 \mathrm{mM} \mathrm{pH} 5.5\end{array}$ & 46.5 & 43.6 & 9.9 \\
\hline 2 & Sodium phosphate $500 \mathrm{mM} \mathrm{pH} \mathrm{5.5}$ & 5.4 & 71.0 & 23.6 \\
\hline \multicolumn{5}{r}{ Percentage composition of glycerides after 90 min of reaction. }
\end{tabular}

We isolated 1,2-diacetin (2) from 2-monacetin by a liquid-liquid separation in which 2-monacetin remained in the aqueous phase and 1,2-diacetin (2) in the organic phase. To ensure complete hydrolysis of triacetin (1), we increased the reaction time to $3 \mathrm{~h}$; finally, a purified 1,2-diacetin (2) structure was corroborated by infrared spectroscopy, ${ }^{1} \mathrm{H}$ NMR and, GCMS (all spectra are found in the Supporting Information, Figures S1-S3).

\subsection{1,2-Diacetin (2) Oxidation with PCC}

To propose new methodologies for the synthesis of glycerol-derived compounds, we attempted to oxidize 1,2-diacetin (2) to glyceraldehyde diacetate (3) (Figure 3) using 2 equivalents of PCC in dichloromethane at $25{ }^{\circ} \mathrm{C}$ for $12 \mathrm{~h}$ (Table 2, entry 1). GCMS analysis showed the formation of the expected glyceraldehyde diacetate (3) (mass spectrum is shown in the Supporting Information, Figure S4) and another compound of higher molecular weight. After filtration through a silica pad, glyceraldehyde diacetate (3) vanished from the reaction crude. Further analysis of the remaining product showed that its structure corresponds to 3-((2,3-diacetoxypropanoyl)oxy)propane-1,2-diyl diacetate (5) (all spectra can be found in the Supporting Information, Figures S5-S9).

The formation of ester (5) can be explained if we take into account that the acidity of PCC can promote a rapid addition of 1,2-diacetin (2) to the glyceraldehyde diacetate (3) to form the dimeric hemiacetal (4), from which subsequent oxidation produces the dimeric ester (5) (Figure 3) [77-79].

To increase the yield of the glyceraldehyde diacetate (3) and to avoid the formation of the hemiacetal (4), which could be promoted by the acidity of PCC, we carried out the reaction adding two equivalents of sodium acetate [80] (Table 2, entry 2) and it was found that decreasing the acidity of the medium promotes the accumulation of the aldehyde (3) with a consequent decrease in the reaction rate. Slow addition of 1,2-diacetin (2), and a higher solvent/PCC ratio (Table 2, entry 3), avoids the formation of ester (5); probably the low concentration of alcohol (2) slows the formation of hemiacetal (4) [78]. 
Accordingly, the best aldehyde proportions were obtained when the reaction was carried out adding only 1 equivalent of sodium acetate and simultaneously reducing the 1,2-diacetin (2) concentration by slow addition and high dilution (Table 2, entry 4) (all chromatograms and mass spectra are shown in the Supporting Information, Figures S10-S16).<smiles>CC(=O)OC(C=O)COC(=O)CCC(=O)OCC(CO)OC(C)=O</smiles>

$(2)+(3)$<smiles></smiles>

(4)<smiles>CC(=O)OCC(COC(=O)C(COC(C)=O)COC(C)=O)OC(C)=O</smiles>

(5)

Figure 3. 1,2-diacetin (2) oxidation and dimeric ester (5) formation; (3) glyceraldehyde diacetate, (4) dimeric hemiacetal.

Table 2. Effects of the reagent and solvent/PCC ratio on 1,2-diacetin oxidation *.

\begin{tabular}{cccc}
\hline Entry & Reagent & Solvent/PCC Ratio & $\begin{array}{c}\text { Ratio (GC) } \\
\text { (2):(5):(3) }\end{array}$ \\
\hline 1 & PCC 2 equiv & $10 \mathrm{~mL} \mathrm{CH}_{2} \mathrm{Cl}_{2} / \mathrm{g} \mathrm{PCC}$ & $4: 6: 1$ \\
\hline 2 & PCC 2 equiv, AcONa 2 equiv & $10 \mathrm{~mL} \mathrm{CH}_{2} \mathrm{Cl}_{2} / \mathrm{g} \mathrm{PCC}$ & $14: 1: 3$ \\
\hline 3 & PCC 2 equiv & $20 \mathrm{~mL} \mathrm{CH}_{2} \mathrm{Cl}_{2} / \mathrm{g} \mathrm{PCC}$ & $3: 8: 4$ \\
\hline 4 & PCC 2 equiv, AcONa 1 equiv & $20 \mathrm{~mL} \mathrm{CH}_{2} \mathrm{Cl}_{2} / \mathrm{g} \mathrm{PCC}$ & $1: 4: 2$ \\
\hline 5 & PCC 2 equiv, AcONa 1 equiv, silica gel $2 \mathrm{~g}$ & $20 \mathrm{~mL} \mathrm{CH}_{2} \mathrm{Cl}_{2} / \mathrm{g} \mathrm{PCC}$ & $1: 5: 1$ \\
\hline
\end{tabular}

* $3 \AA$ A molecular sieves [81] were used in all reactions at room temperature for $12 \mathrm{~h} .{ }^{* *} \mathrm{GC}$ analyses were performed before the reaction workup, as described in Section 3.

It is worth mentioning that glyceraldehyde diacetate (3) could never be isolated for the NMR analysis because the reaction workup promotes the accumulation of the ester (5). Figure 4 shows the reaction's crude (using conditions shown in Table 2 entry 4) composition before and after filtration through a silica pad. During the reaction workup, the unreacted 1,2-diacetin and the produced glyceraldehyde diacetate reacted, to generate compound (5) as the major product in the reaction, no matter which reaction conditions are initially used. We evaluated the effect of silica gel and found that it promotes the accumulation of the dimeric ester (5) (Table 2 entry 5). If celite [82] is used for filtration, the reduced chromium species are not eliminated from the reaction crude; consequently, a silica gel pad must always be used for filtration [83,84].

\subsection{Biological Activity of 3-((2,3-Diacetoxypropanoyl)oxy)propane-1,2-diyl diacetate (5)}

Antimicrobial activity against MRSA, S. aureus ATCC 29213, E. coli ATCC 25922, E. coli O157:H7, S. typhimurium ATCC 14028, S. enteritidis ATCC 13076, P. aeruginosa ATCC 27853, C. albicans ATCC 10231, and C. parapsilosis ATCC 22019 was evaluated. 3-((2,3-diacetoxypropanoyl)oxy)propane-1,2-diyl diacetate does not show growth inhibitory activity at $100 \mathrm{ppm}$ in any of the bacterial strains. However, an increase in the growth of E. coli O157: H7 and Salmonella spp. was evidenced. On the other hand, evaluation of the fungal activity of the dimeric ester showed growth inhibition of both Candida strains at 
$100 \mathrm{ppm}$; the strain C. parapsilosis being the most sensitive with a $68 \%$ inhibition within $48 \mathrm{~h}$ of culturing. Finally, hemolytic activity was evaluated; the new compound presented hemolysis of $18.5 \pm 2.6 \%$ at a concentration of $100 \mathrm{ppm}$, which is considered high, taking into account that a percentage of hemolysis greater than $10 \%$ is considered hemolytic or not hemocompatible [85] (biological activity can be found in the Supporting Information, Figures S17-S19).

To date, this is the first report that describes the synthesis of a new glycerol derivative obtained by enzymatic production of 1,2-diacetin and its posterior oxidation with PCC. The dimeric glycerol ester (5), whose synthesis is herein reported, could be of use for the cosmetics, pharmaceutical, and food industries, and could serve as the starting material for the synthesis of new molecules.
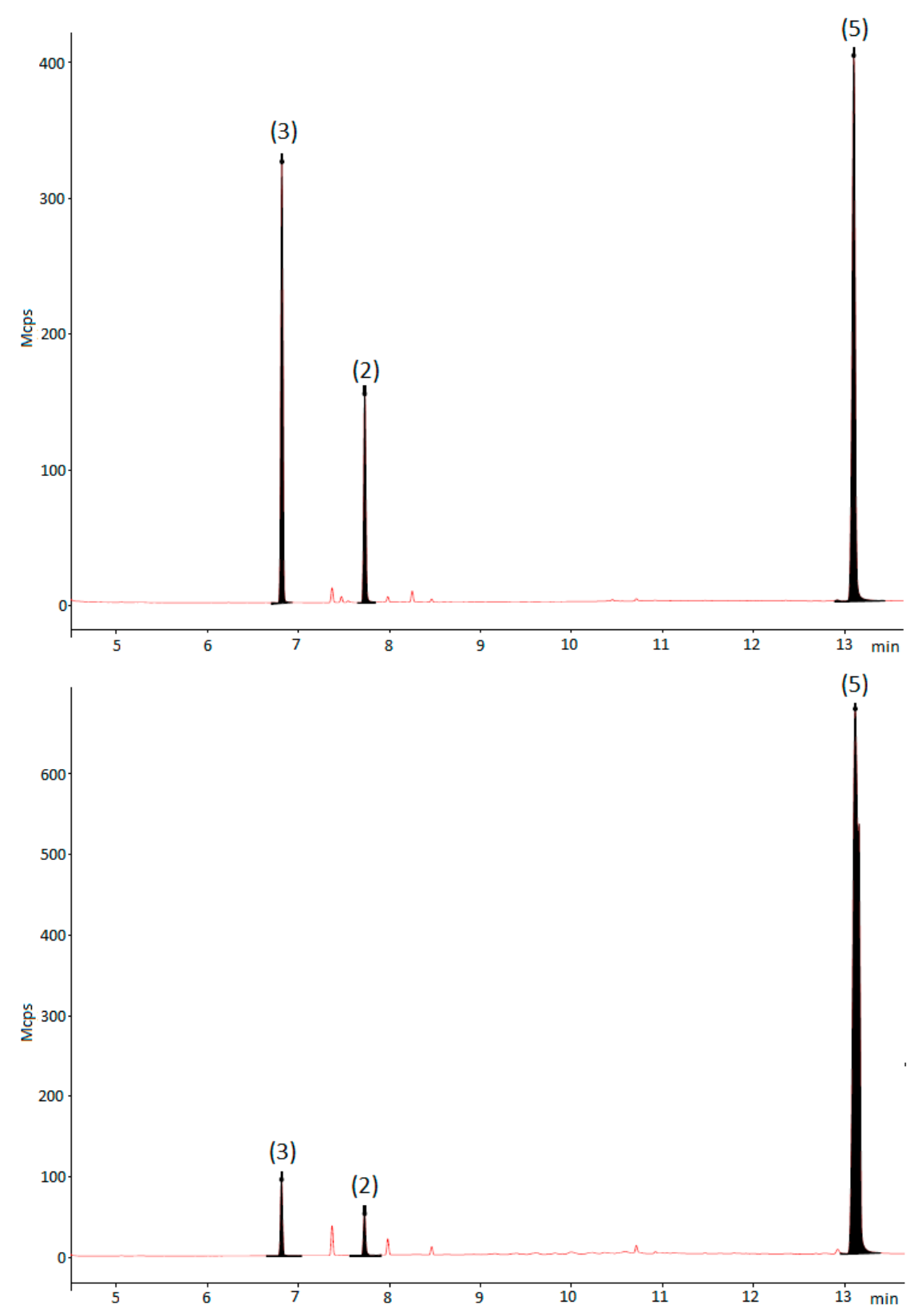

Figure 4. Effect of the reaction workup over the crude composition. Compound notation: (3) glyceraldehyde diacetate, (2) 1,2-diacetin, and (5) 3-((2,3-diacetoxypropanoyl)oxy)propane-1,2-diyl diacetate. Top: GC analysis of the reaction crude performed before the reaction workup. Bottom: GC analysis performed after the reaction's crude filtration through a silica pad. 


\section{Materials and Methods}

Soluble CALB was kindly donated by Novozymes. The octyl Sepharose 4BCL beads were obtained from Sigma Aldrich. Pyridinium chlorochromate was prepared using the Corey and Suggs protocol [46]. Silica gel, 230-400 mesh, molecular sieves of $0.4 \mathrm{~nm}$, dichloromethane, $\mathrm{n}$-hexane, ethyl acetate, and diethyl ether were obtained from Merck. The $p$-nitrophenylbutyrate ( $p$-NPB) was obtained from Sigma Aldrich. Reaction monitoring was performed using silica gel TLC plates (silica Merck 60 F254), and the spots were visualized using Vanillin- $\mathrm{HCl}$ staining. Reaction monitoring was also performed using HPLC-DAD (Agilent Santa Clara, CA, United States) with a Zorbax C-18 $(5 \mu \mathrm{m} \times 250 \mathrm{~mm} \times 4.6 \mathrm{~mm})$ column. ${ }^{1} \mathrm{H}$ and ${ }^{13} \mathrm{C}$ NMR spectra were measured at $25{ }^{\circ} \mathrm{C}$ on a Bruker Advance III-400 spectrometer, using $\mathrm{CDCl}_{3}$ as the solvent. Chemical shifts $(\delta)$ and coupling constants (J) values are reported in ppm and $\mathrm{Hz}$, respectively. Chemical shifts are relative to the solvent peaks used as reference $\left(\mathrm{CDCl}_{3}: \delta 7.26\right.$ for $1 \mathrm{H}$ and $\delta 77.23$ for $\left.{ }^{13} \mathrm{C}\right) .{ }^{1} \mathrm{H}$ NMR assignments were $\mathrm{d}=$ doublet, $\mathrm{s}=$ singlet, $\mathrm{br}=$ broad, and $\mathrm{m}=$ multiplet. Gas chromatograms and low-resolution mass spectra were recorded using a ZB-5 ms $30 \mathrm{~m} \times 0.25 \mathrm{~mm} \times 1.0 \mu \mathrm{m}$ and a $15 \mathrm{~m} \times 0.25 \mathrm{~mm} \times 1.0 \mu \mathrm{m}$ column on a Bruker EVOQ GC-TQ (Bruker Billerica, MA, United States) gas chromatograph (EI: $70 \mathrm{eV}$, full scan); temperature program: $1 \mathrm{~min}$ at $40^{\circ} \mathrm{C}, 40-150{ }^{\circ} \mathrm{C}$ heating at $30^{\circ} \mathrm{C} / \mathrm{min}, 1 \mathrm{~min}$ at $150{ }^{\circ} \mathrm{C}, 150-250{ }^{\circ} \mathrm{C}$ heating at $15^{\circ} \mathrm{C} / \mathrm{min}$, and $3 \mathrm{~min}$ at $250^{\circ} \mathrm{C}$. High-resolution mass spectra were recorded on a Waters Micromass AutoSpect NT operating at $70 \mathrm{eV}$. UHPL-HRMS data were obtained on a Dionex Ultimate 3000 chromatograph accoupled to an Orbitrap Exactive Plus spectrometer via electrospray ionization. Strains of MRSA and E. coli O157:H7 were acquired from a microorganism collection by the Pontificia Universidad Javeriana from Colombia (CMPUJ-certified by the World Federation of Culture Collection). Candida strains were donated by the School of Microbiology of Universidad Industrial de Santander. S. aureus ATCC 29213, E. Coli ATCC25922, P. aeruginosa ATCC 27853, S. enteriditis ATCC13076, and S. Typhimurium ATCC14028 were obtained from ATCC.

\subsection{Standard Activity Determination}

$p$-NPB hydrolysis was used as a model reaction to determine the standard activity during immobilization. A $20-100 \mu \mathrm{L}$ lipase suspension or solution was added to $2.5 \mathrm{~mL}$ of $25 \mathrm{mM}$ sodium phosphate at $\mathrm{pH} 7$ and $25^{\circ} \mathrm{C}$ and the increase in absorbance at $348 \mathrm{~nm}$ produced by the release of $p$-nitrophenol during the hydrolysis of $0.4 \mathrm{mM} p$-NPB was measured [86]. One international unit of activity (U) was defined as the amount of enzyme that hydrolyzes $1 \mu \mathrm{mol}$ of $p$-NPB per minute under the conditions described previously. The protein concentration was determined by Bradford's method using BSA as standard [87].

\subsection{Immobilization of CALB on Octyl agarose beads}

CALB was immobilized on octyl agarose beads at low ionic strength as previously described [34]. A total of $1 \mathrm{~g}$ of octyl sepharose support resuspended in $20 \mathrm{~mL}$ of an enzymatic solution (containing $0.54 \mathrm{mg} / \mathrm{mL}$ of protein and specific activity $10.57 \mathrm{U} / \mathrm{mg}$ ) was gently stirred in a shaker at $250 \mathrm{rpm}$ in phosphate buffer sodium ( $5 \mathrm{mM}$ and $\mathrm{pH} 7$ ). The activities of both the supernatant and suspension were followed using a $p$-NPB assay. After the indicated time, the immobilized enzyme (protein concentration $4 \mathrm{mg} / \mathrm{g}$ of CALB-OC, specific activity $15.5 \mathrm{U} / \mathrm{mg}$ ) was recovered by being filtered and washed several times with distilled water $(3 \times 20 \mathrm{~mL})$.

\subsection{Triacetin (1) Hydrolysis with CALB-OC}

A total of $3.8 \mathrm{~g}$ of CALB-OC were stirred for $3 \mathrm{~h}$ with a solution of $1.9 \mathrm{~mL}(9.95 \mathrm{mmol})$ triacetin in $100 \mathrm{~mL}$ of $500 \mathrm{mM}$ sodium phosphate at $\mathrm{pH} 5.5$ at room temperature. Upon completion of the reaction monitored by HPLC, the biocatalyst was filtered, washed with $30 \mathrm{~mL}$ of distilled water, and stored for reuse. The filtrate was saturated with $\mathrm{NaCl}$ and extracted with dichloromethane $(3 \times 30 \mathrm{~mL})$, the organic layer was washed with brine $(1 \times 20 \mathrm{~mL})$ and dried over sodium sulfate, the solvent was 
removed under reduced pressure to afford $1.297 \mathrm{~g}$ (yield: 74\%, $7.36 \mathrm{mmol}$ ) of 1,2-diacetin as a colorless liquid. IR (ATR): 3462 (O-H), 2957 (C-H), 1734 (C=O), 1217 (C-O ester), 1043 (C-O alcohol). ${ }^{1} \mathrm{H}$ NMR: $\delta=5.09$ to $5.03(\mathrm{~m}, 1 \mathrm{H}, 2-\mathrm{CH}), 4.34-4.17\left(\mathrm{~m}, 2 \mathrm{H}, 3-\mathrm{CH}_{2}\right), 3.72\left(\mathrm{~d}, \mathrm{~J}=5.1 \mathrm{~Hz}, 2 \mathrm{H}, 1-\mathrm{CH}_{2}\right), 2.39(\mathrm{br} \mathrm{s}, 1 \mathrm{H}$, 1-OH), 2.09 (s, 3H, 3-OAc), 2.06(s, 3H, 2-OAc). MS (EI, $70 \mathrm{eV}): \mathrm{m} / \mathrm{z}$ (\%) 145 (11), 103 (15), 43 (100).

\subsection{Synthesis of 3-((2,3-Diacetoxypropanoyl)oxy)propane-1,2-diyl diacetate (5)}

A total of $2.44 \mathrm{~g}(11.35 \mathrm{mmol})$ of PCC, $1 \mathrm{~g}$ of activated molecular sieves, and $23 \mathrm{~mL}$ of dichloromethane were stirred for $10 \mathrm{~min}$ in a round bottom flask, and then a solution of $1 \mathrm{~g}(5.68 \mathrm{mmol})$ of 1,2-diacetin in $5 \mathrm{~mL}$ of dichloromethane was added and the mixture was stirred at $25^{\circ} \mathrm{C}$ for $12 \mathrm{~h}$. Upon completion of the reaction monitored by TLC, $10 \mathrm{~mL}$ of diethyl ether were added to the reaction mixture, which was later filtered through a pad of silica and washed with diethyl ether $(3 \times 10 \mathrm{~mL})$. The solvents were removed under reduced pressure and the remaining crude was purified by column chromatography in silica gel using a 5:2 hexane:ethyl acetate as eluent to afford $0.623 \mathrm{~g}$ (yield 63\%, $1.79 \mathrm{mmol})$ of the product as a colorless liquid. ${ }^{1} \mathrm{H}$ NMR: $\delta=5.32$ to $5.24\left(\mathrm{~m}, 2 \mathrm{H}, 2-\mathrm{CH}, 2^{\prime}-\mathrm{CH}\right), 4.5$ to $4.3\left(\mathrm{~m}, 4 \mathrm{H}, 2^{\prime}-\mathrm{CH}_{2}, 3^{\prime}-\mathrm{CH}_{2}\right), 4.3$ to 4.1 (m, 2H, 3- $\left.\mathrm{CH}_{2}\right), 2.17$ (s, 3H, 3-OAc), 2.09 (s, 6H, 1'-OAc, 2' -OAc), 2.08 (s, 3H, 2-OAc). ${ }^{13} \mathrm{C}$ NMR: $\delta=170.58,170.48,170.21,170.13,167.08,70.38,68.81,63.63,62.60,62.15$, 20.96, 20.81, 20.78, 20.63. MS (IE, $70 \mathrm{eV}): \mathrm{m} / z$ (\%) 173 (17), 159 (12), 145 (13), 131 (7), 103 (15), 43 (100). HRMS (ESI+): $m / z[\mathrm{M}+\mathrm{H}]^{+}$Calculated for $\mathrm{C}_{14} \mathrm{H}_{21} \mathrm{O}_{10}: 349.11347$, found: $349.11307, m / z\left[\mathrm{M}+\mathrm{NH}_{4}\right]^{+}$ Calculated for $\mathrm{C}_{14} \mathrm{H}_{24} \mathrm{O}_{10} \mathrm{~N} 366.1400$, found, 366.13953 .

\subsection{Biological Activity of 3-((2,3-Diacetoxypropanoyl)oxy)propane-1,2-diyl diacetate (5)}

\subsubsection{Antibacterial Activity}

The antimicrobial activity of 3-((2,3-diacetoxypropanoyl)oxy)propane-1,2-diyl diacetate (5) was evaluated by the micro dilution method described in previous works [88,89]. Briefly, a pre-inoculum in Luria Bertani (E. coli ATCC 25922, E. coli O157:H7, S. typhimurium ATCC 14028, S. enteritidis ATCC 13,076, and P. aeruginosa ATCC 27853) and in Mueller Hinton (MH) for MRSA and S. aureus ATCC 29213, were grown at $37^{\circ} \mathrm{C}$ during $12 \mathrm{~h}$ at $200 \mathrm{rpm}$; then, the culture of each strain was set at 0.5 in the McFarland scale $\left(10^{5} \mathrm{CFU} \mathrm{mL}^{-1}\right) ; 100 \mu \mathrm{L}$ aliquots of these cell suspensions were mixed with $100 \mu \mathrm{L}$ of compound (5) at $100 \mathrm{ppm}$ in a 96-well microplate and incubated at $37^{\circ} \mathrm{C}$ in an orbital shaker (200 rpm for $8 \mathrm{~h}$ ). The bacterial growth kinetics of these microbial cultures was performed measuring changes of absorbance at $595 \mathrm{~nm}$ over time in an Elisa reader for these cultures (Thermo Fisher Scientific Waltham, MA, United States). MIC $_{50}$ was defined as the lowest concentration of dimeric ester (5), inhibiting 50\% of the bacterial growth of these bacterial strains. After incubation for $8 \mathrm{~h}, 100 \mu \mathrm{L}$ of these bacterial cultures were poured in $900 \mu \mathrm{L}$ of $\mathrm{BHI}$, incubated at $37^{\circ} \mathrm{C}$ for $24 \mathrm{~h}$, and then a $10 \mu \mathrm{L}$ of these cultures were seeded over $\mathrm{BHI}$-agar petri dishes, incubated for 1 day at $37^{\circ} \mathrm{C}$, after which the appearance of colonies were determined. The MBC was the lowest concentration producing a $>99.9 \%$ reduction in colony-forming units (CFU).

\subsubsection{Antifungal Activity}

The antifungal activity of 3-((2,3-diacetoxypropanoyl)oxy)propane-1,2-diyl (5) diacetate was evaluated over C. parapsilosis ATCC 22,019 and C. albicans ATCC 10,231 by the microdilution method described in previous works [90]. From a fresh culture, a suspension was adjusted to an absorbance of $0.09-0.13$ at $490 \mathrm{~nm}$ in sterile saline solution $\left(10^{6} \mathrm{CFU} \mathrm{mL}^{-1}\right)$. Once adjusted, a dilution was carried on Roswell Park Memorial Institute medium (RPMI) to obtain a concentration of $10^{3} \mathrm{CFU} \mathrm{mL}^{-1}$, which was inoculated in 96-well plates with $100 \mathrm{ppm}$ of compound (5) and incubated at $37^{\circ} \mathrm{C}$ for $48 \mathrm{~h}$. Once the incubation time was over, the absorbance at $490 \mathrm{~nm}$ was measured in a microplate reader (Thermo Scientific ${ }^{\mathrm{TM}}$, Multiskan Sky) and compared with the selected growth controls. 


\subsubsection{Hemolytic Activity}

The hemolytic activity of compound 3-((2,3-diacetoxypropanoyl)oxy)propane-1,2-diyl diacetate (5) on sheep erythrocytes was evaluated, adapting the method described in previous works [91,92]. From $1 \mathrm{~mL}$ of defibrinated blood, three serial washes were carried out with $0.9 \%$ saline solution and the cell density was adjusted to $1 \% v / v$ by using cell counting in a Neubauer chamber. Then, $100 \mu \mathrm{L}$ aliquots of the adjusted suspension were transferred to 96-well microplates and incubated with one containing a $100 \mathrm{ppm}$ solution of compound (5), and were incubated for $3 \mathrm{~h}$ at $37^{\circ} \mathrm{C}$. The microplates were centrifuged at $500 \times g$ in $5 \mathrm{~min}$ and the absorbance of the released hemoglobin was measured at $543 \mathrm{~nm}$ using a microplate reader (Thermo Scientific ${ }^{\mathrm{TM}}$, Multiskan Sky). Saline solution and $0.5 \%$ triton $\mathrm{X}-100$ were used as the negative and positive controls, respectively. To determine the percentage of hemolysis, Equation (1) was used.

$$
\%_{\text {hemolysis }}=\frac{(A m-A c n)}{\left(A_{C p}-A_{c n}\right)} \times 100
$$

where Am is the absorbance of the sample, Acp is the absorbance of the positive control, and Acn is the absorbance of the negative control.

\section{Conclusions}

In this work, we have shown that immobilized lipases are very useful tools for the synthesis of new glycerol value-added derivatives. We developed a chemoenzymatic methodology for the synthesis of a new glycerol dimeric ester, in which we made use of CALB immobilized on octyl-agarose, which proved to be an efficient biocatalyst for the regioselective hydrolysis of triglycerides, to synthesize under mild conditions 1,2-diacetin, which was subsequently oxidized with PCC. Interestingly, this oxidation did not afford the expected aldehyde but a dimeric ester through a mechanism that involves the condensation of the starting diglyceride and the product aldehyde. Finally, the dimeric glycerol ester obtained has antifungal activity; however, it does not show activity on bacterial growth, which allows us to establish that it is a biologically active compound on eukaryotic cells. The hemolytic activity was evaluated, and the results obtained support the use of the dimeric ester to control C. albicans and C. parapsilosis growth in non-intravenous applications because the compound produces hemolysis at the evaluated concentration.

Supplementary Materials: Supplementary Materials Figures S1-S19 are available online at http://www.mdpi. com/1422-0067/21/18/6501/s1.

Author Contributions: Investigation: E.P., M.R. and J.R.; manuscript writing-review and editing: E.P., M.R., J.C.C., C.O. and R.F.-L.; funding acquisition: J.J.C., R.F.L. and C.O.; supervision: R.F.-L., J.C.C. and C.O.; conceptualization: R.F.-L.; methodology: E.P, M.R. and J.R. All authors have read and agreed to the published version of the manuscript.

Funding: This research was funded by Colciencias, project number FP 44842-076-2016, and Universidad Industrial de Santander (Vicerrectoría de Investigación y Extension, project number 8854) and Spanish Ministerio de Ciencia e Innovación, grant number CTQ2017-86170-R.

Acknowledgments: We gratefully recognize the support from Elena Stashenko (CENIVAM-UIS). The help and suggestions from Ángel Berenguer (Departamento de Química Inorgánica, Universidad de Alicante) are gratefully recognized. We thank Jerson Andres Martinez Lozano (GIBIM-UIS) for the hemolytic activity experiments.

Conflicts of Interest: The authors declare no conflict of interest. The funders had no role in the design of the study; in the collection, analyses, or interpretation of data; in the writing of the manuscript, or in the decision to publish the results. 


\section{Abbreviations}

$\begin{array}{ll}\text { CALB } & \text { Candida antarctica } \\ \text { CALB-OC } & \text { Candida antarctica immobilized on octyl-agarose } \\ \text { PCC } & \text { pyridinium chlorochromate } \\ \text { IR } & \text { infrared spectroscopy } \\ \text { NMR } & \text { nuclear magnetic resonance } \\ \text { MS } & \text { mass spectrometry } \\ \text { HR } & \text { high resolution } \\ \text { PGs } & \text { polyglycerols } \\ \text { PGEs } & \text { polyglycerol esters } \\ \text { MIC } 50 & \text { minimal inhibitory concentration } \\ \text { MRSA } & \text { methicillin-resistant Staphylococcus aureus }\end{array}$

\section{References}

1. Atadashi, I.M.; Aroua, M.K.; Abdul Aziz, A.R.; Sulaiman, N.M.N. The effects of catalysts in biodiesel production: A review. J. Ind. Eng. Chem. 2013, 19, 14-26. [CrossRef]

2. Semwal, S.; Arora, A.K.; Badoni, R.P.; Tuli, D.K. Biodiesel production using heterogeneous catalysts. Bioresour. Technol. 2011, 102, 2151-2161. [CrossRef]

3. Zhao, X.; Qi, F.; Yuan, C.; Du, W.; Liu, D. Lipase-catalyzed process for biodiesel production: Enzyme immobilization, process simulation and optimization. Renew. Sustain. Energy Rev. 2015, 44, 182-197. [CrossRef]

4. Manaf, I.S.A.; Embong, N.H.; Khazaai, S.N.M.; Rahim, M.H.A.; Yusoff, M.M.; Lee, K.T.; Maniam, G.P. A review for key challenges of the development of biodiesel industry. Energy Convers. Manag. 2019, 185, 508-517. [CrossRef]

5. Mendiara, T.; García-Labiano, F.; Abad, A.; Gayán, P.; de Diego, L.F.; Izquierdo, M.T.; Adánez, J. Negative $\mathrm{CO} 2$ emissions through the use of biofuels in chemical looping technology: A review. Appl. Energy 2018, 232, 657-684. [CrossRef]

6. Vivek, N.; Sindhu, R.; Madhavan, A.; Anju, A.J.; Castro, E.; Faraco, V.; Pandey, A.; Binod, P. Recent advances in the production of value added chemicals and lipids utilizing biodiesel industry generated crude glycerol as a substrate-Metabolic aspects, challenges and possibilities: An overview. Bioresour. Technol. 2017, 239, 507-517. [CrossRef] [PubMed]

7. Luo, X.; Ge, X.; Cui, S.; Li, Y. Value-added processing of crude glycerol into chemicals and polymers. Bioresour. Technol. 2016, 215, 144-154. [CrossRef] [PubMed]

8. Yang, F.; Hanna, M.A.; Sun, R. Value-added uses for crude glycerol-a byproduct of biodiesel production. Biotechnol. Biofuels 2012, 5, 13. [CrossRef]

9. Talebian-Kiakalaieh, A.; Amin, N.A.S.; Rajaei, K.; Tarighi, S. Oxidation of bio-renewable glycerol to value-added chemicals through catalytic and electro-chemical processes. Appl. Energy 2018, 230, 1347-1379. [CrossRef]

10. Xu, Y.; Nordblad, M.; Nielsen, P.M.; Brask, J.; Woodley, J.M. In situ visualization and effect of glycerol in lipase-catalyzed ethanolysis of rapeseed oil. J. Mol. Catal. B Enzym. 2011, 72, 213-219. [CrossRef]

11. Kristensen, J.; Xu, X.; Mu, H. Diacylglycerol synthesis by enzymatic glycerolysis: Screening of commercially available lipases. J. Am. Oil Chem. Soc. 2005, 82, 329-334. [CrossRef]

12. Sánchez, D.A.; Tonetto, G.M.; Ferreira, M.L. Valorization of glycerol through the enzymatic synthesis of acylglycerides with high nutritional value. Catalysts 2020, 10, 116. [CrossRef]

13. Zheng, Y.; Chen, X.; Shen, Y. Erratum: Commodity chemicals derived from glycerol, an important biorefinery feedstock (Chemical Reviews (2008) 108 (5253)). Chem. Rev. 2010, 110, 1807. [CrossRef] [PubMed]

14. Ferretti, C.A.; Soldano, A.; Apesteguía, C.R.; Di Cosimo, J.I. Monoglyceride synthesis by glycerolysis of methyl oleate on solid acid-base catalysts. Chem. Eng. J. 2010, 161, 346-354. [CrossRef]

15. Rarokar, N.R.; Menghani, S.; Kerzare, D.; Khedekar, P.B. Progress in Synthesis of Monoglycerides for Use in Food and Pharmaceuticals. J. Exp. Food Chem. 2017, 03, 1-6. [CrossRef]

16. Zeng, F.; Yang, B.; Wang, Y.; Wang, W.; Ning, Z.; Li, L. Enzymatic Production of Monoacylglycerols with Camellia Oil by the Glycerolysis Reaction. J. Am. Oil Chem. Soc. 2010, 87, 531-537. [CrossRef] 
17. Santaniello, E.; Casati, S.; Ciuffreda, P. Lipase-Catalyzed Deacylation by Alcoholysis: A Selective, Useful Transesterification Reaction. Curr. Org. Chem. 2006, 10, 1095-1123. [CrossRef]

18. Sonntag, N.O.V. Glycerolysis of fats and methyl esters-Status, review and critique. J. Am. Oil Chem. Soc. 1982, 59, 795A-802A. [CrossRef]

19. Davis, B.G.; Boyer, V. Biocatalysis and enzymes in organic synthesis. Nat. Prod. Rep. 2001, 18, 618-640. [CrossRef]

20. Gotor-Fernández, V.; Vicente, G. Use of Lipases in Organic Synthesis. In Industrial Enzymes: Structure, Function and Applications; Springer: Berlin/Heidelberg, Germany, 2007; pp. 301-315.

21. Anderson, E.M.; Larsson, K.M.; Kirk, O. One Biocatalyst-Many Applications: The Use of Candida Antarctica B-Lipase in Organic Synthesis. Biocatal. Biotransformation 1998, 16, 181-204. [CrossRef]

22. Manova, D.; Gallier, F.; Tak-Tak, L.; Yotava, L.; Lubin-Germain, N. Lipase-catalyzed amidation of carboxylic acid and amines. Tetrahedron Lett. 2018, 59, 2086-2090. [CrossRef]

23. Diaz-Vidal, T.; Armenta-Perez, V.P.; Rosales-Rivera, L.C.; Mateos-Díaz, J.C.; Rodríguez, J.A. Cross-linked enzyme aggregates of recombinant Candida antarctica lipase B for the efficient synthesis of olvanil, a nonpungent capsaicin analogue. Biotechnol. Prog. 2019, 35, 1-11. [CrossRef] [PubMed]

24. Stergiou, P.-Y.; Foukis, A.; Filippou, M.; Koukouritaki, M.; Parapouli, M.; Theodorou, L.G.; Hatziloukas, E.; Afendra, A.; Pandey, A.; Papamichael, E.M. Advances in lipase-catalyzed esterification reactions. Biotechnol. Adv. 2013, 31, 1846-1859. [CrossRef] [PubMed]

25. Ghanem, A.; Aboul-Enein, H.Y. Application of lipases in kinetic resolution of racemates. Chirality 2005, 17, 1-15. [CrossRef]

26. Berglund, P. Controlling lipase enantioselectivity for organic synthesis. Biomol. Eng. 2001, 18, 13-22. [CrossRef]

27. Kumar, A.; Dhar, K.; Kanwar, S.S.; Arora, P.K. Lipase catalysis in organic solvents: Advantages and applications. Biol. Proced. Online 2016, 18, 2. [CrossRef]

28. Adlercreutz, P. Immobilisation and application of lipases in organic media. Chem. Soc. Rev. 2013, 42, 6406-6436. [CrossRef]

29. Verger, R. 'Interfacial activation' of lipases: Facts and artifacts. Trends Biotechnol. 1997, 15, 32-38. [CrossRef]

30. Schmid, R.D.; Verger, R. Lipases: Interfacial Enzymes with Attractive Applications. Angew. Chem. Int. Ed. Engl. 1998, 37, 1608-1633. [CrossRef]

31. Zisis, T.; Freddolino, P.L.; Turunen, P.; van Teeseling, M.C.F.; Rowan, A.E.; Blank, K.G. Interfacial Activation of Candida antarctica Lipase B: Combined Evidence from Experiment and Simulation. Biochemistry 2015, 54, 5969-5979. [CrossRef]

32. Manoel, E.A.; dos Santos, J.C.S.; Freire, D.M.G.; Rueda, N.; Fernandez-Lafuente, R. Immobilization of lipases on hydrophobic supports involves the open form of the enzyme. Enzyme Microb. Technol. 2015, 71, 53-57. [CrossRef] [PubMed]

33. Stauch, B.; Fisher, S.J.; Cianci, M. Open and closed states of Candida antarctica lipase B: Protonation and the mechanism of interfacial activation. J. Lipid Res. 2015, 56, 2348-2358. [CrossRef]

34. Bastida, A.; Sabuquillo, P.; Armisen, P.; Fernández-Lafuente, R.; Huguet, J.; Guisán, J.M. A single step purification, immobilization, and hyperactivation of lipases via interfacial adsorption on strongly hydrophobic supports. Biotechnol. Bioeng. 1998, 58, 486-493. [CrossRef]

35. Fernandez-Lafuente, R.; Armisén, P.; Sabuquillo, P.; Fernández-Lorente, G.; Guisán, J.M. Immobilization of lipases by selective adsorption on hydrophobic supports. Chem. Phys. Lipids 1998, 93, 185-197. [CrossRef]

36. Rodrigues, R.C.; Virgen-Ortíz, J.J.; dos Santos, J.C.S.; Berenguer-Murcia, Á.; Alcantara, A.R.; Barbosa, O.; Ortiz, C.; Fernandez-Lafuente, R. Immobilization of lipases on hydrophobic supports: Immobilization mechanism, advantages, problems, and solutions. Biotechnol. Adv. 2019, 37, 746-770. [CrossRef] [PubMed]

37. Ortiz, C.; Ferreira, M.L.; Barbosa, O.; dos Santos, J.C.S.; Rodrigues, R.C.; Berenguer-Murcia, Á.; Briand, L.E.; Fernandez-Lafuente, R. Novozym 435: The "perfect" lipase immobilized biocatalyst? Catal. Sci. Technol. 2019, 9, 2380-2420. [CrossRef]

38. Yang, L.; Li, X.; Chen, P.; Hou, Z. Selective oxidation of glycerol in a base-free aqueous solution: A short review. Chinese J. Catal. 2019, 40, 1020-1034. [CrossRef]

39. Razali, N.; Abdullah, A.Z. Production of lactic acid from glycerol via chemical conversion using solid catalyst: A review. Appl. Catal. A Gen. 2017, 543, 234-246. [CrossRef] 
40. Habe, H.; Fukuoka, T.; Kitamoto, D.; Sakaki, K. Biotechnological production of d-glyceric acid and its application. Appl. Microbiol. Biotechnol. 2009, 84, 445-452. [CrossRef]

41. El Roz, A.; Fongarland, P.; Dumeignil, F.; Capron, M. Glycerol to glyceraldehyde oxidation reaction over Pt-based catalysts under base-free conditions. Front. Chem. 2019, 7, 1-9. [CrossRef]

42. Dodekatos, G.; Schünemann, S.; Tüysüz, H. Recent Advances in Thermo-, Photo-, and Electrocatalytic Glycerol Oxidation. ACS Catal. 2018, 8, 6301-6333. [CrossRef]

43. Katryniok, B.; Kimura, H.; Skrzyńska, E.; Girardon, J.S.; Fongarland, P.; Capron, M.; Ducoulombier, R.; Mimura, N.; Paul, S.; Dumeignil, F. Selective catalytic oxidation of glycerol: Perspectives for high value chemicals. Green Chem. 2011, 13, 1960-1979. [CrossRef]

44. Skrzyńska, E.; Ftouni, J.; Mamede, A.-S.; Addad, A.; Trentesaux, M.; Girardon, J.-S.; Capron, M.; Dumeignil, F. Glycerol oxidation over gold supported catalysts- “Two faces" of sulphur based anchoring agent. J. Mol. Catal. A Chem. 2014, 382, 71-78. [CrossRef]

45. Collins, J.C.; Hess, W.W. Aldehydes from Primary Alcohols by Oxidation with Chromium Trioxide: Heptanal. Org. Synth. 2003, 5.

46. Corey, E.J.; Suggs, J.W. Pyridinium chlorochromate. An efficient reagent for oxidation of primary and secondary alcohols to carbonyl compounds. Tetrahedron Lett. 1975, 16, 2647-2650. [CrossRef]

47. Corey, E.J.; Schmidt, G. Useful procedures for the oxidation of alcohols involving pyridinium dichromate in approtic media. Tetrahedron Lett. 1979, 20, 399-402. [CrossRef]

48. Katre, S.D. Applications of Chromium ( VI ) Complexes as Oxidants in Organic Synthesis: A Brief Review. Der Pharma Chemica 2018, 10, 12-16.

49. Patel, S.; Mishra, B.K. Chromium(VI) oxidants having quaternary ammonium ions: Studies on synthetic applications and oxidation kinetics. Tetrahedron 2007, 63, 4367-4406. [CrossRef]

50. Sivaiah, M.V.; Robles-Manuel, S.; Valange, S.; Barrault, J. Recent developments in acid and base-catalyzed etherification of glycerol to polyglycerols. Catal. Today 2012, 198, 305-313. [CrossRef]

51. Martin, A.; Richter, M. Oligomerization of glycerol-A critical review. Eur. J. Lipid Sci. Technol. 2011, 113, 100-117. [CrossRef]

52. Salehpour, S.; Dubé, M.A. Towards the Sustainable Production of Higher-Molecular-Weight Polyglycerol. Macromol. Chem. Phys. 2011, 212, 1284-1293. [CrossRef]

53. Calderón, M.; Quadir, M.A.; Sharma, S.K.; Haag, R. Dendritic polyglycerols for biomedical applications. Adv. Mater. 2010, 22, 190-218. [CrossRef] [PubMed]

54. Tang, Q.; Li, X.; Dong, J. Selective Synthesis of Diglycerol Monoacetals via Catalyst-Transfer in Biphasic System and Assessment of their Surfactant Properties. ACS Sustain. Chem. Eng. 2018, 6, 16813-16818. [CrossRef]

55. Clacens, J.-M.; Pouilloux, Y.; Barrault, J. Selective etherification of glycerol to polyglycerols over impregnated basic MCM-41 type mesoporous catalysts. Appl. Catal. A Gen. 2002, 227, 181-190. [CrossRef]

56. Shimazaki, A.; Sakamoto, J.J.; Furuta, M.; Tsuchido, T. Antifungal Activity of Diglycerin Ester of Fatty Acids against Yeasts and Its Comparison with Those of Sucrose Monopalmitate and Sodium Benzoate. Biocontrol Sci. 2016, 21, 123-130. [CrossRef]

57. Nguyen, R.; Galy, N.; Singh, A.; Paulus, F.; Stöbener, D.; Schlesener, C.; Sharma, S.; Haag, R.; Len, C. A Simple and Efficient Process for Large Scale Glycerol Oligomerization by Microwave Irradiation. Catalysts 2017, 7, 123. [CrossRef]

58. Kansy, D.; Bosowska, K.; Czaja, K.; Poliwoda, A. The Formation of Glycerol Oligomers with Two New Types of End Groups in the Presence of a Homogeneous Alkaline Catalyst. Polymers (Basel) 2019, 11, 144. [CrossRef]

59. Ayoub, M.; Abdullah, A.Z.; Ahmad, M.; Sultana, S. Performance of lithium modified zeolite Y catalyst in solvent-free conversion of glycerol to polyglycerols. J. Taibah Univ. Sci. 2014, 8, 231-235. [CrossRef]

60. Gholami, Z.; Abdullah, A.Z.; Lee, K.T. Catalytic Etherification of Glycerol to Diglycerol Over Heterogeneous Calcium-Based Mixed-Oxide Catalyst: Reusability and Stability. Chem. Eng. Commun. 2014, 202, 1397-1405. [CrossRef]

61. Boudrant, J.; Woodley, J.M.; Fernandez-Lafuente, R. Parameters necessary to define an immobilized enzyme preparation. Process. Biochem. 2020, 90, 66-80. [CrossRef]

62. Ruiz, M.; Galvis, M.; Barbosa, O.; Ortiz, C.; Torres, R.; Fernandez-Lafuente, R. Solid-phase modification with succinic polyethyleneglycol of aminated lipase B from Candida antarctica: Effect of the immobilization protocol on enzyme catalytic properties. J. Mol. Catal. B Enzym. 2013, 87, 75-82. [CrossRef] 
63. Barbosa, O.; Ruiz, M.; Ortiz, C.; Fernández, M.; Torres, R.; Fernandez-Lafuente, R. Modulation of the properties of immobilized CALB by chemical modification with 2,3,4-trinitrobenzenesulfonate or ethylendiamine. Advantages of using adsorbed lipases on hydrophobic supports. Process. Biochem. 2012, 47, 867-876. [CrossRef]

64. Trodler, P.; Pleiss, J. Modeling structure and flexibility of Candida antarctica lipase B in organic solvents. BMC Struct. Biol. 2008, 8, 9. [CrossRef] [PubMed]

65. Martinelle, M.; Holmquist, M.; Hult, K. On the interfacial activation of Candida antarctica lipase A and B as compared with Humicola lanuginosa lipase. Biochim. Biophys. Acta-Lipids Lipid Metab. 1995, 1258, 272-276. [CrossRef]

66. Arana-Peña, S.; Lokha, Y.; Fernández-Lafuente, R. Immobilization on octyl-agarose beads and some catalytic features of commercial preparations of lipase a from Candida antarctica (Novocor ADL): Comparison with immobilized lipase B from Candida antarctica. Biotechnol. Prog. 2019, 35, e2735. [CrossRef]

67. Kapoor, M.; Gupta, M. Lipase Promiscuity and its biochemical applications. Process. Biochem. 2012, 47, 555-569. [CrossRef]

68. Rueda, N.; dos Santos, J.C.S.; Torres, R.; Ortiz, C.; Barbosa, O.; Fernandez-Lafuente, R. Improved performance of lipases immobilized on heterofunctional octyl-glyoxyl agarose beads. RSC Adv. 2015, 5, 11212-11222. [CrossRef]

69. Hernandez, K.; Garcia-Verdugo, E.; Porcar, R.; Fernandez-Lafuente, R. Hydrolysis of triacetin catalyzed by immobilized lipases: Effect of the immobilization protocol and experimental conditions on diacetin yield. Enzyme Microb. Technol. 2011, 48, 510-517. [CrossRef]

70. Hirata, D.B.; Albuquerque, T.L.; Rueda, N.; Virgen-Ortíz, J.J.; Tacias-Pascacio, V.G.; Fernandez-Lafuente, R. Evaluation of different immobilized lipases in transesterification reactions using tributyrin: Advantages of the heterofunctional octyl agarose beads. J. Mol. Catal. B Enzym. 2016, 133, 117-123. [CrossRef]

71. Hirata, D.B.; Albuquerque, T.L.; Rueda, N.; Sánchez-Montero, J.M.; Garcia-Verdugo, E.; Porcar, R.; Fernandez-Lafuente, R. Advantages of Heterofunctional Octyl Supports: Production of 1,2-Dibutyrin by Specific and Selective Hydrolysis of Tributyrin Catalyzed by Immobilized Lipases. ChemistrySelect 2016, 1, 3259-3270. [CrossRef]

72. Hernandez, K.; Garcia-Galan, C.; Fernandez-Lafuente, R. Simple and efficient immobilization of lipase B from Candida antarctica on porous styrene-divinylbenzene beads. Enzyme Microb. Technol. 2011, 49, 72-78. [CrossRef] [PubMed]

73. Villalba, M.; Verdasco-Martín, C.M.; dos Santos, J.C.S.; Fernandez-Lafuente, R.; Otero, C. Operational stabilities of different chemical derivatives of Novozym 435 in an alcoholysis reaction. Enzyme Microb. Technol. 2016, 90, 35-44. [CrossRef] [PubMed]

74. Cabrera, Z.; Fernandez-Lorente, G.; Fernandez-Lafuente, R.; Palomo, J.M.; Guisan, J.M. Novozym 435 displays very different selectivity compared to lipase from Candida antarctica B adsorbed on other hydrophobic supports. J. Mol. Catal. B Enzym. 2009, 57, 171-176. [CrossRef]

75. Li, W.; Du, W.; Li, Q.; Sun, T.; Liu, D. Study on acyl migration kinetics of partial glycerides: Dependence on temperature and water activity. J. Mol. Catal. B Enzym. 2009, 63, 17-22. [CrossRef]

76. Palomo, J. Modulation of Enzymes Selectivity Via Immobilization. Curr. Org. Synth. 2009, 6, 1-14. [CrossRef]

77. Papaioannou, D.; Francis, G.W.; Aksnes, D.W.; Brekke, T.; Maartmann-Moe, K. Studies on the Oxidation of Methyl 2,3-O-Isopropylidene-beta-D-ribofuranoside with Pyridinium Dichromate. Identification of Unexpected By-Products. Acta Chem. Scand. 1990, 44, 90-95. [CrossRef]

78. Ermolenko, L.; Sasaki, N.A.; Potier, P. An Expedient One-Step Preparation of (S)-2,3-O-Isopropylideneglyceraldehyde. Synlett 2001, 2001, 1565-1566. [CrossRef]

79. Crombie, L.; Ryan, A.P.; Whiting, D.A.; Yeboah, S.O. Synthesis of 4'-O-methyl- and 4',6-di-O-methylchalaurenol. J. Chem. Soc. Perkin Trans. 1987, 1, 2783-2786. [CrossRef]

80. Taber, D.F.; Christos, T.E.; Hodge, C.N. Cyclohexenone Annelation by Alkylidene C-H Insertion: Synthesis of Oxo-T-cadinol. J. Org. Chem. 1996, 61, 2081-2084. [CrossRef]

81. Adams, L.L.; Luzzio, F.A. Ultrasound in oxochromium(VI)-amine-mediated oxidations - modifications of the Corey-Suggs oxidation for the facile conversion of alcohols to carbonyl compounds. J. Org. Chem. 1989, 54, 5387-5390. [CrossRef]

82. Wipf, P.; Jung, J.-K. Formal Total Synthesis of (+)-Diepoxin o. J. Org. Chem. 2000, 65, 6319-6337. [CrossRef] [PubMed] 
83. Deiters, A.; Mück-Lichtenfeld, C.; Fröhlich, R.; Hoppe, D. Planar-Chiral (2E,7Z)- and (2Z,7E)Cyclonona-2,7-dien-1-yl Carbamates by Asymmetric, Bis-Allylic $\alpha, \alpha^{\prime}$-Cycloalkylation-Studies on Their Conformational Stability. Chem. A Eur. J. 2002, 8, 1833-1842. [CrossRef]

84. Luzzio, F.A.; Fitch, R.W.; Moore, W.J.; Mudd, K.J. A Facile Oxidation of Alcohols Using Pyridinium Chlorochromate/Silica Gel. J. Chem. Educ. 1999, 76, 974. [CrossRef]

85. Amin, K.; Dannenfelser, R.-M. In vitro hemolysis: Guidance for the pharmaceutical scientist. J. Pharm. Sci. 2006, 95, 1173-1176. [CrossRef]

86. Quinn, D.M.; Shirai, K.; Jackson, R.L.; Harmony, J.A. Lipoprotein lipase catalyzed hydrolysis of water-soluble p-nitrophenyl esters. Inhibition by apolipoprotein C-II. Biochemistry 1982, 21, 6872-6879. [CrossRef]

87. Bradford, M.M. A rapid and sensitive method for the quantitation of microgram quantities of protein utilizing the principle of protein-dye binding. Anal. Biochem. 1976, 72, 248-254. [CrossRef]

88. Paredes, D.; Ortiz, C.; Torres, R. Synthesis, characterization, and evaluation of antibacterial effect of Ag nanoparticles against Escherichia coli O157:H7 and methicillin-resistant Staphylococcus aureus (MRSA). Int. J. Nanomedicine 2014, 9, 1717-1729. [CrossRef]

89. Cruz, J.; Flórez, J.; Torres, R.; Urquiza, M.; Gutiérrez, J.A.; Guzmán, F.; Ortiz, C.C. Antimicrobial activity of a new synthetic peptide loaded in polylactic acid or poly(lactic-co-glycolic) acid nanoparticles against Pseudomonas aeruginosa, Escherichia coli O157:H7 and methicillin resistant Staphylococcus aureus (MRSA). Nanotechnology 2017, 28, 135102. [CrossRef]

90. Reference Method for Broth Dilution Antifungal Susceptibility Testing of Yeast. Clinical Laboratory Standards Institute. Available online: https://clsi.org/standards/products/microbiology/documents/m27/ (accessed on 24 August 2020).

91. Krzyzaniak, J.F.; Nuúnñez, F.A.A.; Raymond, D.M.; Yalkowsky, S.H. Lysis of human red blood cells. 4. Comparison of in vitro and in vivo hemolysis data. J. Pharm. Sci. 1997, 86, 1215-1217. [CrossRef]

92. Helmerhorst, E.J.; Reijnders, I.M.; van 't Hof, W.; Veerman, E.C.I.; Nieuw Amerongen, A.V. A critical comparison of the hemolytic and fungicidal activities of cationic antimicrobial peptides. FEBS Lett. 1999, 449, 105-110. [CrossRef] 